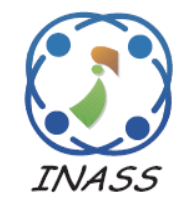

\title{
Performance Evaluation of DTNs Routing Protocols on Train System by Variations in Message Volume
}

\author{
Agus Urip Ari Wibowo ${ }^{1,2} \quad$ Selo Sulistyo $^{1^{*}} \quad$ I Wayan Mustika $^{1} \quad$ Afdhil Hafid $^{1}$ \\ ${ }^{1}$ Department of Electrical Engineering and Information Technology, Faculty of Engineering, \\ Universitas Gadjah Mada, Yogyakarta, Indonesia \\ ${ }^{2}$ Department of Computer, Politeknik Caltex Riau, Pekanbaru, Indonesia \\ * Corresponding author's Email: selo@ugm.ac.id
}

\begin{abstract}
In this world, there are areas, the villages that have not received the spread of messages (e.g. goverment's information) through Internet. For the villages that are be served by scheduled public transports systems at least once a day there is an opportunity to receive messages from the Internet. The public transports serve as relay nodes that carry the messages from the cities that are to be sent to the villages. This paper compares Delay and DisruptionTolerant Networks (DTNs) routing protocols to solve the problem of the spread of messages. The scenario is made based on the local map with realistic environment. The parameters used in the simulation are the speed of public transport $1.478 \mathrm{~m} / \mathrm{sec}$, some transmit ranges, several buffer sizes, and some message sizes by number of differences. The simulation shows that the routing protocol MaxProp gets better delivery probability than other routing protocols. However, all the routing protocols produce better delivery probability on larger size and smaller number of messages.
\end{abstract}

Keywords: Message spreading, Internet, Public transport, Delay- and Disruption-Tolerant Networks, Routing protocol.

\section{Introduction}

One of the problems faced by governments in developing countries is to spread the information quickly to the suburbs called villages. One of the information spreading ways is Internet. Areas that have sufficient network infrastructure to always be connected to the Internet, cities have benefit to gain information quickly. Some suburban areas do not have adequate network infrastructure to always be connected to the Internet. Therefore, the region does not have benefits from the information spreading through the Internet. The Indonesian government has done various ways to spread the information such as setting up Media Center [1-4], providing vehicle assistance counseling public information Car Center for Community Information Technology or Mobil Pusat Teknologi Informasi Komunitas (MPUSTIKA) [5,6], and developing Layar Desa or TV Desa program $[7,8]$.
Media Center is a medium of public information dissemination, exchange of information, and public information and communication services [9]. The media center is located in various provinces, cities, and regencies in Indonesia. The existence of the Media Center is expected to encourage the public to get information that is accurate, fast, easy, and affordable. Media Center uses the information and communication technology media is a computer, scanner, printer, and Internet connection. Expense cost for Internet package is given for 6 months [10]. The advantages are the information can be obtained quickly, but it requires a communications network infrastructure that is always connected to the Internet, the costs, and the operator.

M-PUSTIKA is the Indonesian Government's efforts in disseminating information to the remote villages and outlying areas in Indonesia [6]. The government provides public information counseling using two and four wheels vehicles in various provinces, cities, and regencies [5]. Dissemination 
of information is not just one way, but it is interactive. M-PUSTIKA equipped with communication devices such as netbooks, speakers, projectors, speakers, and diesel engine portable. The advantages are the operator can move from one place to another and there are interactions, but had no connection to the Internet.

The Village Screen or the Village TV is the government programs in the provision of information to the public until in remote villages across Indonesia, especially the border regions [8]. This program provides a screen measuring three by four meters in every village that has been set. The screen is equipped with auxiliary devices so that the public gets national broadcast via satellite. The display device is installed on land that is provided in the office of the village head so that residents can enjoy the program broadcast this village for free. This is done because the television media only reaches 40 percent of Indonesia [7]. The advantage is that people enjoy it for free, but requires a connection to the satellites.

If the area does not have adequate network infrastructure but it is served by public transport systems, such as buses or trains, this area has an opportunity to build Wireless Local Area Networks (WLANs) [11,12] using Delay- and DisruptionTolerant Networks (DTNs) architecture [13]. The DTNs architecture is able to adapt to different types of networks that have particular challenges and can provide access to Internet services in remote areas [14]. In [12,15], the DTNs have been applied to connect developing areas, connect disconnected areas, monitor the environment and wildlife, and used on projects in urban areas.

In the developing areas, the DTNs are used on the project DakNet by using buses, motorcycles, and bicycles as relay nodes [16], KioskNet using buses and cars [17], a system of Internet services countryside by trains [18-20], and remote consultation services [21-23]. In the disconnected areas of the project are Saami Network Connectivity (SNC) using volunteers [24,25] and the local mining using trucks and miners [26]. The ZebraNet project that uses Wireless Sensor Networks (WSNs) [27,28] is an example of the use of the DTNs to monitor the environment and wildlife. DTNs usage in urban areas is DieselNet which serves to collect information and is used to improve the DTNs routing protocol algorithms by using a testbed of 40 buses [29]. Some applications that use DTNs are Twitter [30], the search engine [31], and BikeNet application that is used to collect information from bicycle routes [32].
The DTNs architecture has also been simulated to send messages to a remote village by buses, boats, and other public transports [33] and communications ship-to-ship in the maritime environment networks [34]. In [33], the model of public transport motion is unknown. The sizes of messages used are 25, 50, 75, and 100 MBytes, but the number of messages each message size is unknown. Instead, the actual vessel movement data is used in [34]. The simulation was performed with transmit range $1-50 \mathrm{Km}$, infinite buffer size and time to live, and size of 10 MByte message. The simulation was performed with three scenarios. Each scenario has a different observation area and involves a number of different ships. The number of vessels were observed 26, 41, and 99.

From the above discussion, areas which do not have adequate network infrastructures, but it is served by a scheduled public transport using the DTNs architecture have not been discussed deeply nor been used in spreading the information. The scheduled public transport can also be used to gather information about the condition of agricultural areas and farms in the village. Moreover, performance evaluation of the DTNs routing protocols in such situation has not been done and presented. This paper discusses how the DTNs routing protocols using scheduled public transport are used to spread the message from cities to villages. The propose system is evaluated using a simulator Opportunistic Network Environment (ONE).

The rest of this paper is organized as follows. Section 2 describes the simulation and parameters used. Results and discussion are described in Section 3. Conclusion is presented in Section 4.

\section{Simulation}

\subsection{Map}

The simulator that is used is Opportunistic Network Environment (ONE) and requires a scenario. The scenario is created by considering a local map with realistic environment. This paper uses a railway A-B based on the local map of Google Map. The railway can be seen in Fig. 1. Figure 2 shows some LINESTRINGs that have coordinates. These LINESTRINGs are created using OpenJUMP based on Fig. 1. Based on Figs. 1 and 2, it is obtained the actual railway that is about 166 Kilometers. The area that is served by the railway has a size of $187 \mathrm{Km} \times 53 \mathrm{Km}$. The length of the railway that is created has a size of 1 to 10 to the actual railway length. 


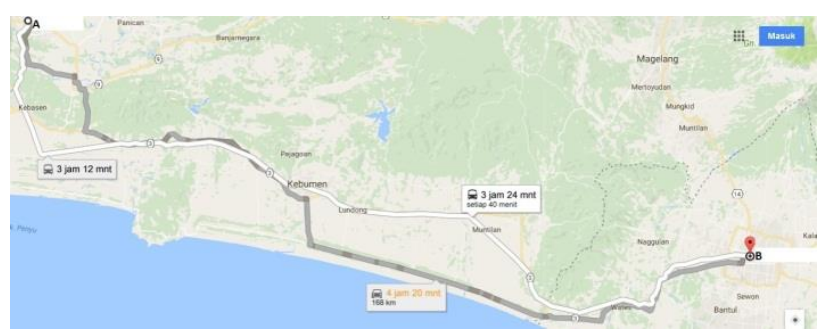

Figure.1 The railway A-B of Google Map

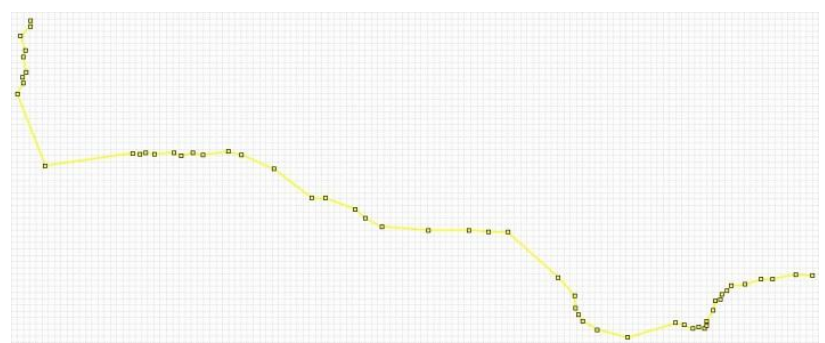

Figure. 2 The railway line A-B of OpenJUMP

Table 1. Train schedule A-B

\begin{tabular}{|l|l|l|}
\hline Time & Route & Name \\
\hline $00: 26$ & A-B & KA 1 \\
\hline $01: 15$ & A-B & KA 2 \\
\hline $01: 55$ & A-B & KA 3 \\
\hline $02: 57$ & A-B & KA 4 \\
\hline $03: 20$ & A-B & KA 5 \\
\hline $07: 00$ & B-A & KA 11 \\
\hline $08: 00$ & B-A & KA 12 \\
\hline $08: 57$ & B-A & KA 13 \\
\hline $09: 00$ & B-A & KA 14 \\
\hline $11: 42$ & A-B & KA 6 \\
\hline $12: 58$ & A-B & KA 7 \\
\hline $14: 00$ & A-B & KA 8 \\
\hline $17: 45$ & B-A & KA 15 \\
\hline $18: 35$ & B-A & KA 16 \\
\hline $20: 00$ & B-A & KA 17 \\
\hline $20: 35$ & B-A & KA 18 \\
\hline $20: 57$ & B-A & KA 19 \\
\hline $21: 40$ & A-B & KA 9 \\
\hline $22: 00$ & B-A & KA 20 \\
\hline $22: 37$ & A-B & KA 10 \\
\hline
\end{tabular}

\subsection{Node}

The first group models use static motion models (StationaryMovement). There are two cities or source nodes and three villages or destination nodes. Sources have coordinates that are located at A and B. Destinations have coordinates in the railway A-B. Sources and destinations have a distance of about 2 meters (equivalent to the actual distance of 20 meters) from the railway based on PerMen PU [35].

Train schedule on railway A-B is obtained from [36]. This schedule can be seen in Table 1. The schedule is divided into 10 schedule relay nodes from $\mathrm{A}$ to $\mathrm{B}$ (A-B) and 10 from $\mathrm{B}$ to $\mathrm{A}$ (B-A). Earliest departing time from $\mathrm{A}$ is at 00:26 and the
Table 2. Message

\begin{tabular}{|c|c|c|}
\hline $\begin{array}{l}\text { Size } \\
\text { (KByte) }\end{array}$ & $\begin{array}{l}\text { Number } \\
\text { message }\end{array}$ & $\begin{array}{ll}\text { Time } \\
\text { (second) }\end{array}$ \\
\hline 100 & 132 & Every 3600 \\
\hline 90 & 147 & Every 3240 \\
\hline 80 & 165 & Every 2880 \\
\hline 70 & 189 & Every 2520 \\
\hline 60 & 220 & Every 2160 \\
\hline 50 & 264 & Every 1800 \\
\hline 40 & 330 & Every 1440 \\
\hline 30 & 440 & Every 1080 \\
\hline 20 & 660 & Every 720 \\
\hline 10 & 1320 & Every 360 \\
\hline 9 & 1467 & Every 324 \\
\hline 8 & 1650 & Every 288 \\
\hline 7 & 1886 & Every 252 \\
\hline 6 & 2200 & Every 216 \\
\hline 5 & 2640 & Every 180 \\
\hline 4 & 3300 & Every 144 \\
\hline 3 & 4400 & Every 108 \\
\hline 2 & 6600 & Every 72 \\
\hline 1 & 13200 & Every 36 \\
\hline
\end{tabular}

last is at 22:37. Earliest departing time from B is at 07:00 and the last is at 22:00. Start and end schedule are used to determine the length of the simulation and the start and end of messages to be sent from sources to destinations. Differences in departing time relay nodes are used to estimate the buffer size required to temporarily store messages to be sent from sources to destinations.

The railway length $(16600 \mathrm{~m})$ affects the velocity of the second group (relay nodes) that has 1 to 10 speeds to the actual speed. Based on the length of the railway and the relay nodes duration on the railway, the lowest speed of the relay node is 1.478 $\mathrm{m} / \mathrm{sec}$ (equivalent to $53.21 \mathrm{~km} / \mathrm{h}$ ). LINESTRING coordinates and the lowest speed are used as a reference motion scheduled relay nodes using an ExternalMovement motion model. Motion scheduled relay nodes are stored in a file that contains the time (when) and the coordinates of the point (where) of each relay node. This file is used by ONE as a real trace.

\subsection{Message}

The message sizes sent from the sources to the destinations by using relay nodes are $1 \mathrm{KByte}$ to 100 KBytes. Three messages of 100 KBytes are generated from source at $\mathrm{A}$ and $\mathrm{B}$ to three destinations at every hour. Therefore, six messages with total size of $600 \mathrm{KBytes}$ are generated by two sources at every hour (3600 seconds).

Based on the schedule, the last relay node in one of the sources is at 22:00. If the first message is 
generated at 00:00 and the last message is generated at 21:00, then the message transmit occurs 22 times in each source. The number of transmit is 22 , the number of each message sent is six, and the size of each message sent is $100 \mathrm{KBytes}$, then it is obtained the total message size sent is 13200 KBytes. The total message size with a size other than 100 KBytes is also arranged for 13200 KBytes. If the size of each message is $50 \mathrm{KBytes}$ and the total message size is $13200 \mathrm{KBytes}$, then the time needed to send messages from any source is every 30 minutes (1800 seconds). The message size, number of message, and sending time of message can be seen in Table 2 .

\subsection{Simulation Parameter}

Table 3 shows the simulation parameters used by the simulator ONE. Scheduled motion relay nodes are obtained using ExternalMovement. The simulation is performed based on the size and number of messages. The size and number of messages are obtained using ExternalEventsQueue.

Table 3. Paramater simulator ONE

\begin{tabular}{|c|c|}
\hline Parameter & Value \\
\hline End time & 93000 seconds \\
\hline Transmit speed & $750 \mathrm{KByte} / \mathrm{sec}=6 \mathrm{Mbit} / \mathrm{sec}$ \\
\hline Transmit range & $(10,20,30,40,50)$ meter \\
\hline Number of host groups & $\begin{array}{l}3 \text { (2 sources, } 3 \text { destinations, } \\
20 \text { relay nodes })\end{array}$ \\
\hline Routing protocols & $\begin{array}{l}\text { FirstContactRouter, } \\
\text { EpidemicRouter, } \\
\text { ProphetRouter, } \\
\text { ProphetV2Router, } \\
\text { MaxPropRouter }\end{array}$ \\
\hline Buffer size & $(1,5,10)$ MByte \\
\hline Message TTL & 720 minutes $=12$ hours \\
\hline Relay node movement model & ExternalMovement \\
\hline Relay node speed & $1.478 \mathrm{~m} / \mathrm{sec}$ \\
\hline $\begin{array}{l}\text { Source and destination node } \\
\text { movement model }\end{array}$ & StationaryMovement \\
\hline Message generator & ExternalEventsqueue \\
\hline Message generator file & 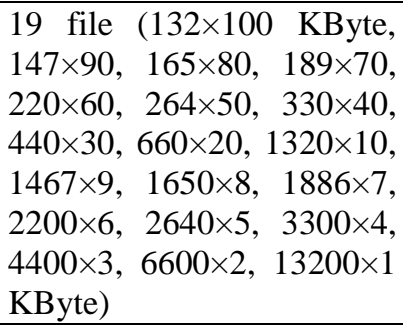 \\
\hline Simulation area & $18700 \mathrm{~m} \times 5300 \mathrm{~m}$ \\
\hline
\end{tabular}

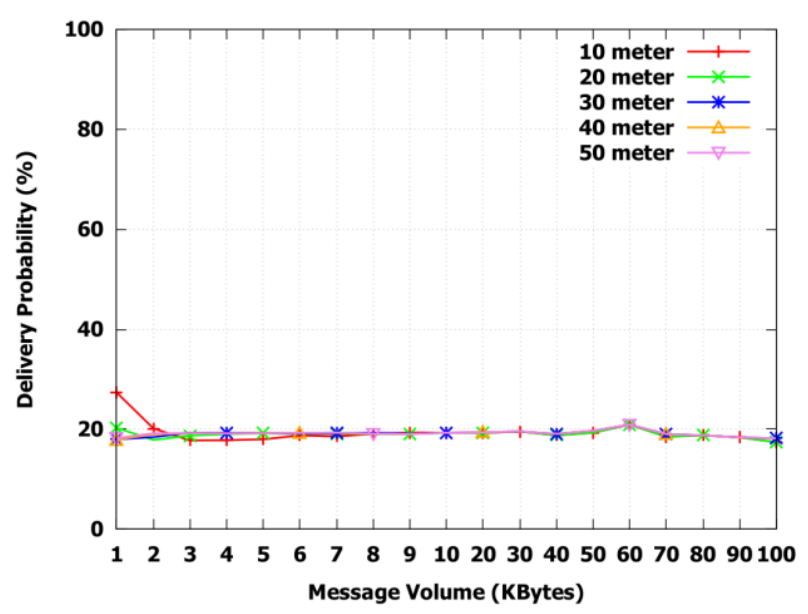

Figure.3 First-contact with a buffer size of 1 MByte

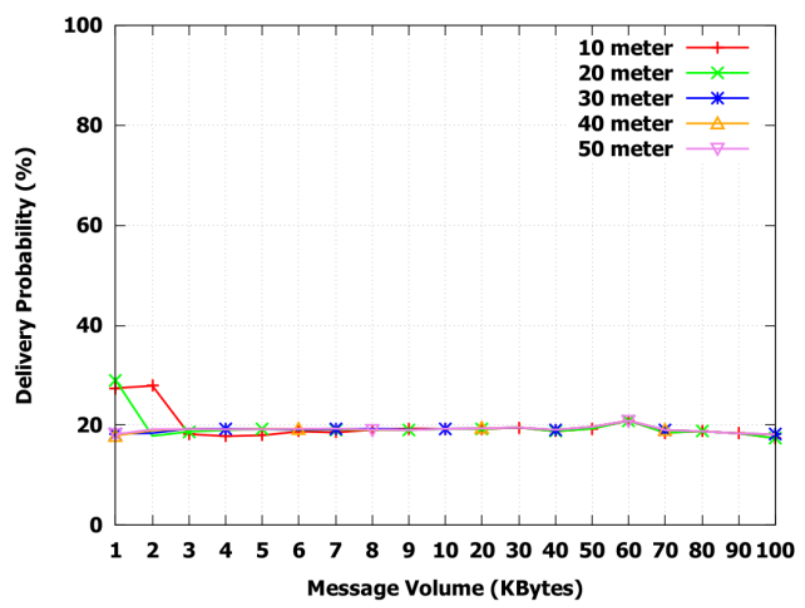

Figure.4 First-contact with the buffer size of 5 Mbytes

\section{Result and Discussion}

\subsection{First-Contact}

In the first-contact, the source node forwarding a message to relay node firstly met and the process repeats until the message is received by the destination node. The destination node is randomly searched. Oscillation message may occur on a set of nodes and cause the message to be undelivered to the destination node [37].

Figures 3 to 5 show that by increasing the buffer size does not cause a significant increase in the delivery probability. The highest delivery probability (close to $30 \%$ ) is at the size of 1 KByte message on all buffer sizes. More than $70 \%$ of messages cannot be sent to the destinations because of the possibility of the oscillation message among the relay nodes and the sources. 


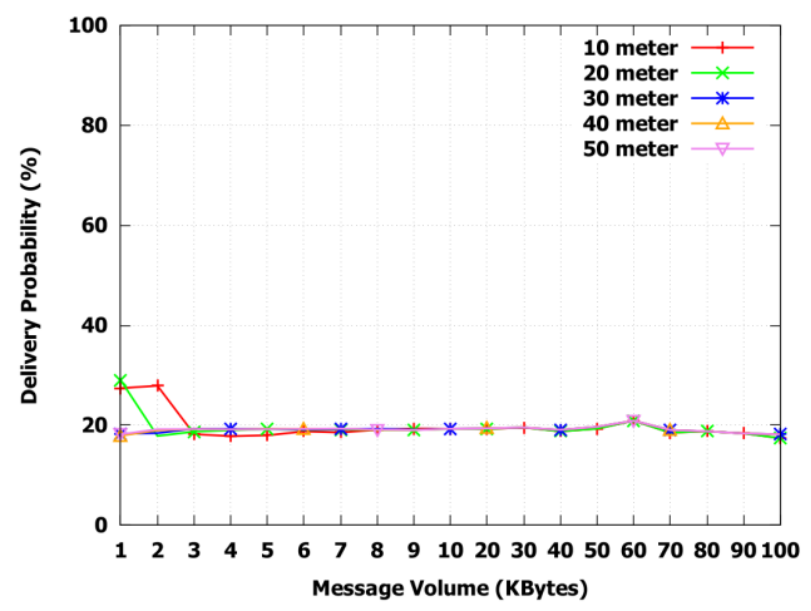

Figure.5 First-contact with the buffer size of 10 Mbytes

\subsection{Epidemic}

The spread of diseases in real life is an analogy of the epidemic routing protocol. The concept of store-carry-forward (scf) is a node storing received messages, to bring it while moving, and to send it on another node when meeting. The infection process occurs if the receiving node does not have a copy of the message from the sender node. Infected nodes do the same when they meet other uninfected nodes. After infecting multiple nodes in a network, the message is finally received by the destination node. The purpose of the epidemic is to maximize the messaging opportunities, minimizing messaging latency, and minimizing the resources used in the delivery of messages (eg: bandwidth and energy) [38]. Epidemic requires two steps, the exchange of vector summaries and the exchange messages if the vector summary contents are different [39].

Based on [40], the epidemic is effective but if the density of nodes on the network increases, that will cause message flood. It makes lots of buffer space conflict and requires bandwidth, causing many bundle drops and requires retransmission in the network with limited resources. The epidemic provides optimal solutions in networks with unlimited buffer and unlimited bandwidth.

Based on Figs. 6 to 8 that by increasing the buffer size causes increased delivery probability of more than 2 times $80 \%$ (5 MBytes) compared to $30 \%$ (1 MByte) and reach the best 100\% (10 MBytes). The delivery probability of $100 \%$ is achieved by message of $8 \mathrm{KBytes}$ to $100 \mathrm{KBytes}$ in all transmit ranges. The epidemic shows that by increasing the buffer size, it gives an impact on improving the delivery probability.

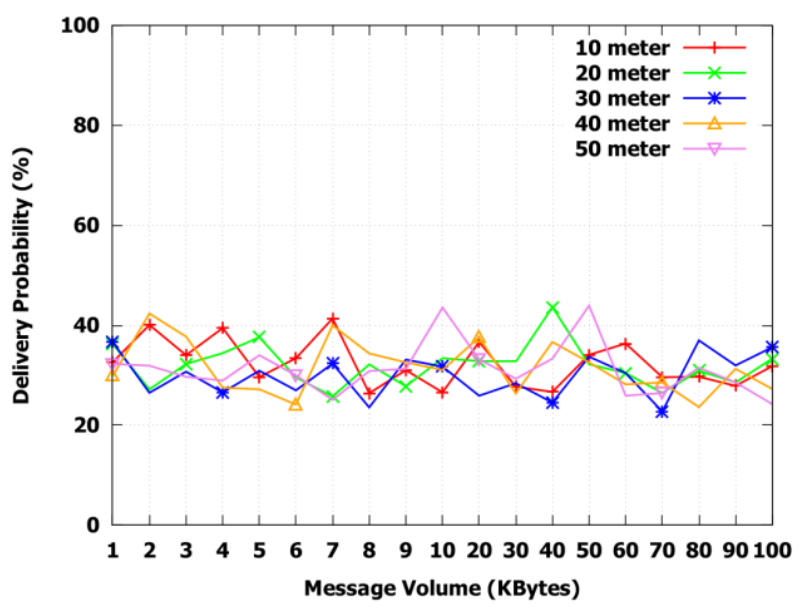

Figure.6 Epidemic with a buffer size of 1 MByte

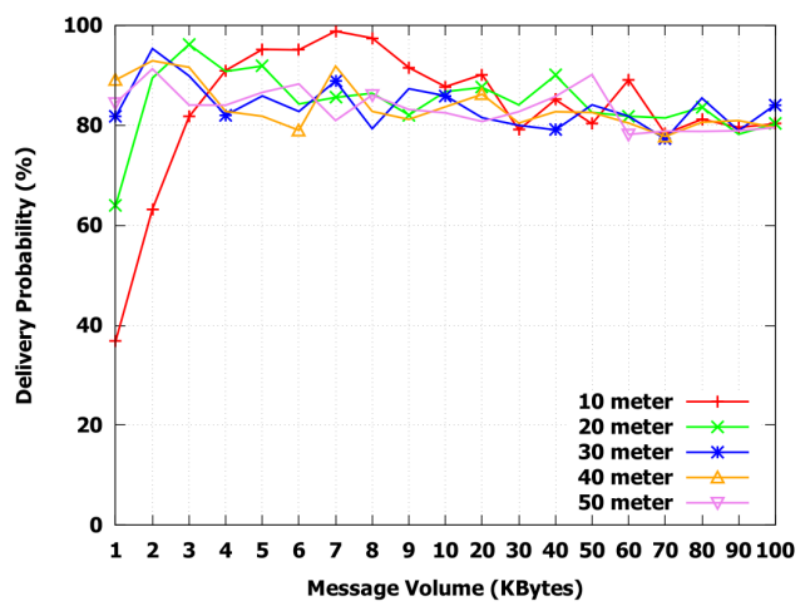

Figure.7 Epidemic with a buffer size of 5 MBytes

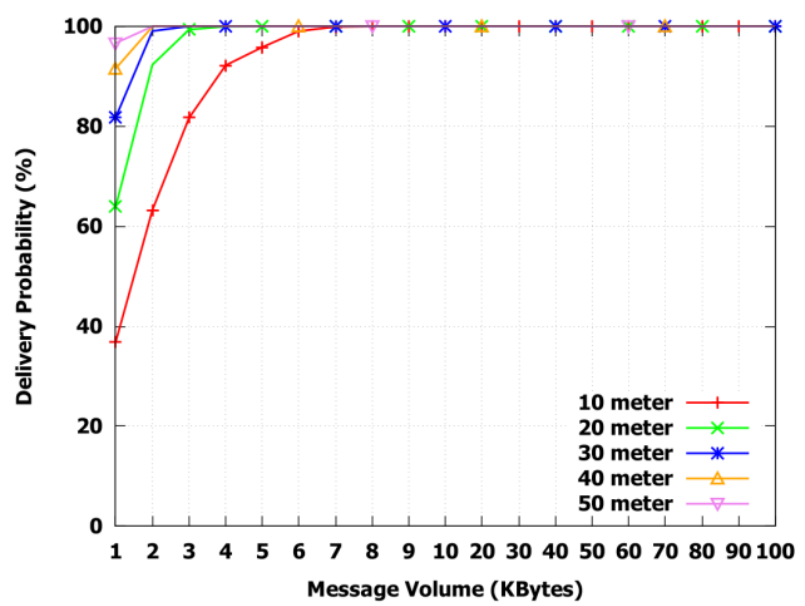

Figure.8 Epidemic with a buffer size of 10 Mbytes

\subsection{PRoPHET}

In general, a mobile ad hoc evaluation protocol uses a random way-point mobility model that has been popular. In fact, a node does not move randomly and can be predicted based on repetitive patterns of behavior. If a node has visited the site 
several times before, there is a possibility that the node will visit the site again [41].

The use of the non-randomized mobility and improved performance routing protocol is the basis of probability. This probability routing protocol is named Probabilistic Routing Protocol using History of Encounters and Transitivity (PRoPHET).

This protocol uses the concept of history meeting node and transitivity properties. The history meeting node defines $\mathrm{P}(\mathrm{a}, \mathrm{b})$ the probability that two nodes, A and B, meet each other. This probability is called the delivery predictability (DP). The value of $\mathrm{P}(\mathrm{a}, \mathrm{b})$ between 0 and $1, \mathrm{P}(\mathrm{a}, \mathrm{b}) \in[0,1]$. This probability is updated at each successive meeting between the same nodes. This probability can also diminish in value over time if the nodes are not met. Thus, between the two meetings, the delivery predictability can be reduced.

Transitivity property $\mathrm{P}(\mathrm{a}, \mathrm{c})$ of the $\mathrm{DP}$ is based on the observation if the node $\mathrm{A}$ and node $\mathrm{B}$ are often met and the node B and node $\mathrm{C}$ are often met. Node B may be a good node to forward the message to the destination node $\mathrm{C}$ and vice versa.

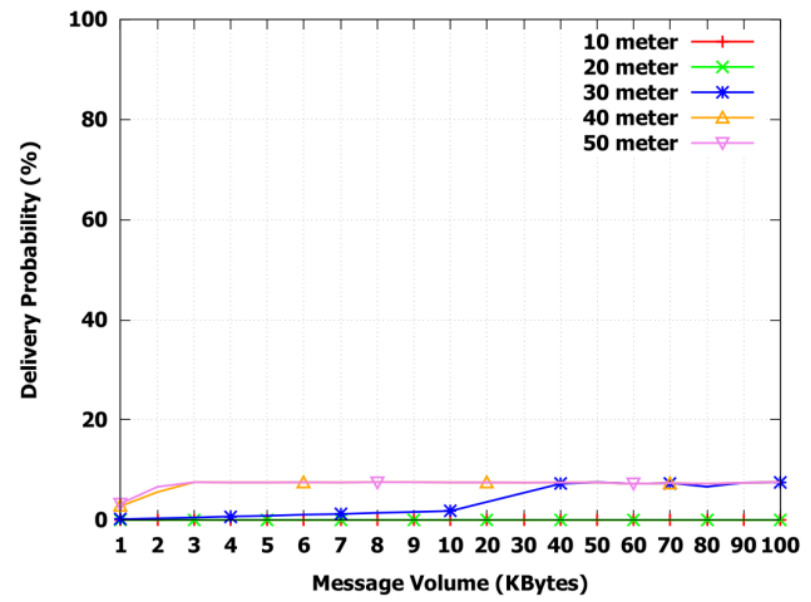

Figure.9 PRoPHET with a buffer size of 1 MByte

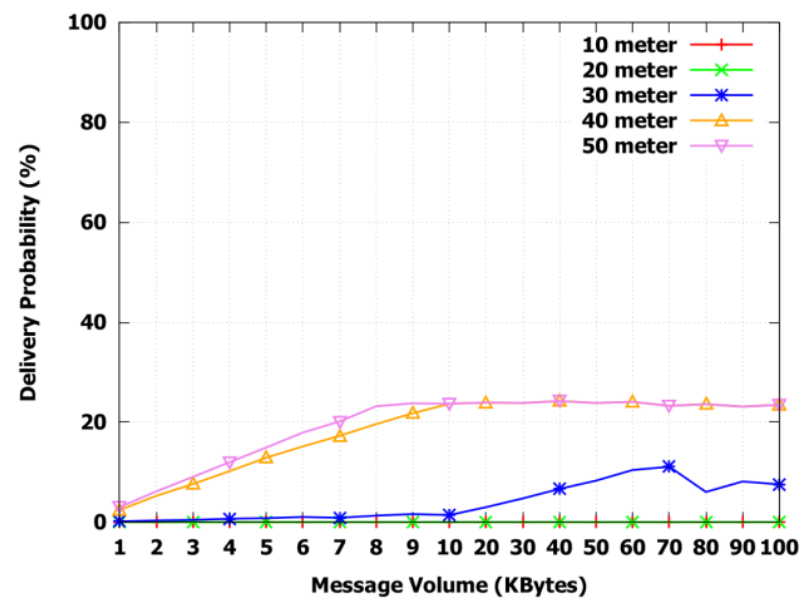

Figure.10 PRoPHET with a buffer size of 5 Mbytes

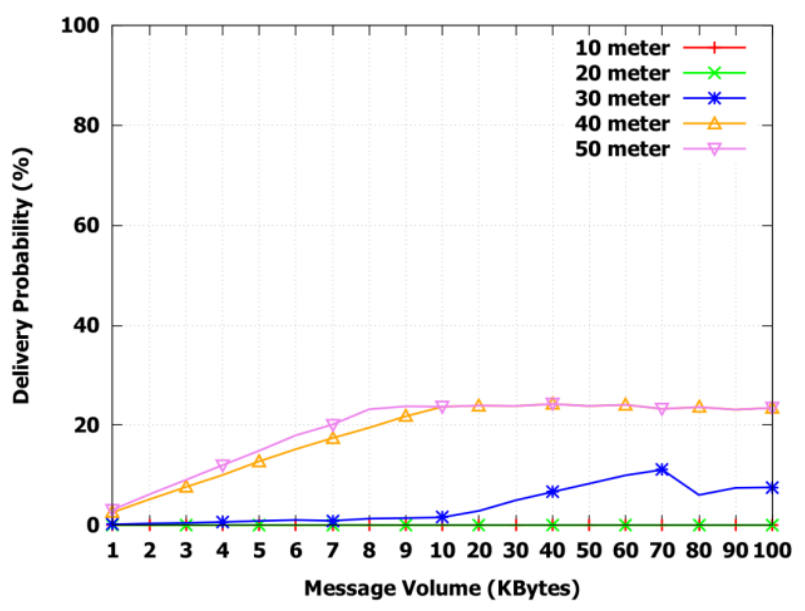

Figure.11 PRoPHET with a buffer size of 10 MBytes

DP value is calculated on all the network nodes for each destination known. This value is updated each time a node meets and used to decide whether to send or not to send messages at communication opportunities. If two nodes are met, they exchange the DP information stored on them. They use this information to update their own estimated DP information. Based on this information and the message destination, the message is sent to another node if the DP message destination is higher in the other node.

Based on Figs. 9 to 11, by increasing the buffer size causes increased delivery probability of more than 3 times approaching 25\% (5 MBytes) compared to less than $8 \%$ (1 MByte). However, there is no increase of 10 MBytes compared to 5 MBytes as they both approach $25 \%$. It occurs because there is a possibility that the message is sent to the relay node away from the destination after meeting the destination. The relay node has the value delivery predictability (DP) destination that has been bypassed higher.

\subsection{PRoPHETv2}

Grasic et al. [42] indicated a problem with parking lot on the PRoPHET. Observations on the parking lot show that the movement does not happen in accordance with the scale of human movement patterns typical for hours or days. Devices in the parking lot have multiple reconnections among themselves which are considered as "new" meeting due to Wi-Fi signals fluctuate in short time periods. Grasic et al. observed that the DP will always keep increasing.

To solve the parking lot problem on the PRoPHET, Grasic et al. [42] proposed an improved version of the protocol that is the PRoPHETv2. 
These improvements led the PRoPHETv2 to be able to stabilize the value of the enlarged DP unexpected.

Figures 12 to 14 show that by increasing the buffer size causes increased delivery probability about 2 times, close to $33 \%$ (5 MBytes) compared to approaching $16 \%$ (1 MByte). However, there is no increase of 10 MBytes compared to 5 MBytes as they both approach $33 \%$. The PRoPHETv2 is better than the PRoPHET because the PRoPHETv2 has to solve the parking lot problem.

\subsection{MaxProp}

A generic routing protocol for vehicular DTNs is MaxProp (Burgess et al., 2006 [27]) [40]. This protocol performs routing with priority scheduling to forward messages at contact opportunities and scheduling to drop messages because the buffer is overflowed. To calculate these priorities, the protocol uses the historical data on the path probabilities to nodes.

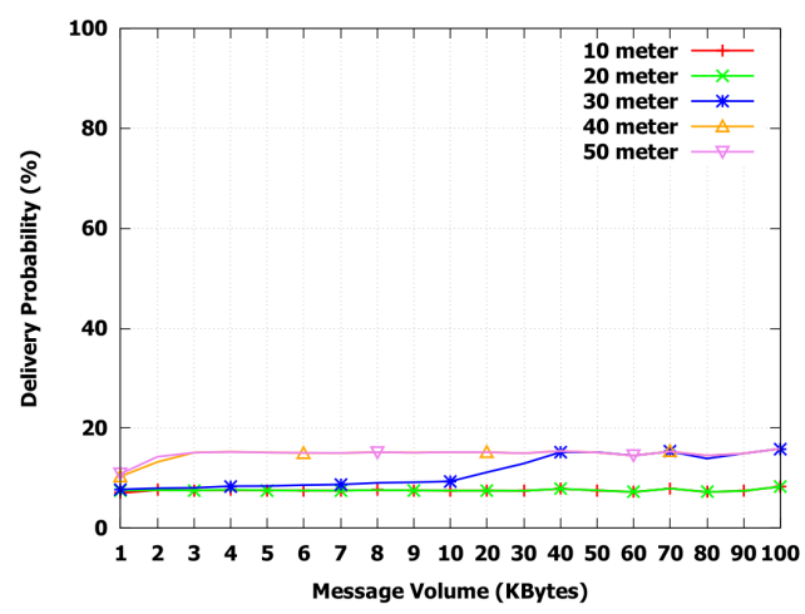

Figure.12 PRoPHETv2 with a buffer size of 1 MByte

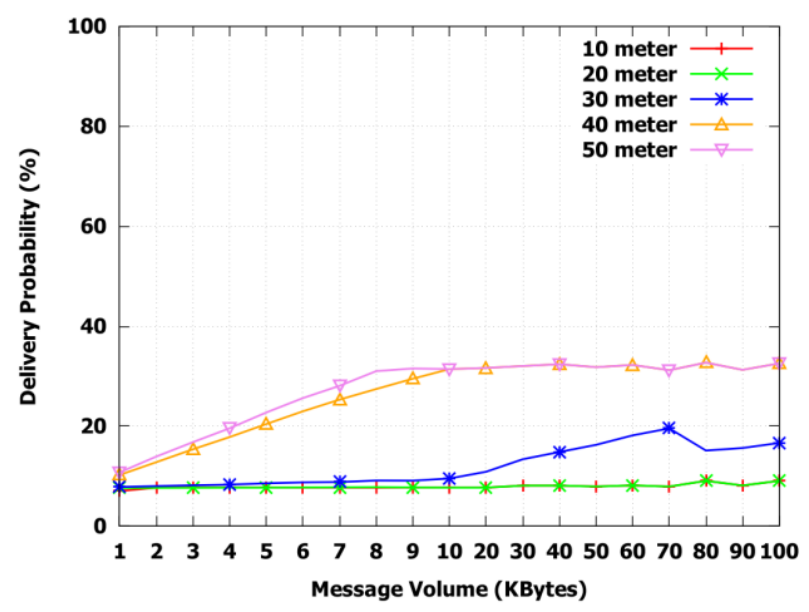

Figure.13 PRoPHETv2 with a buffer size of 5 MBytes

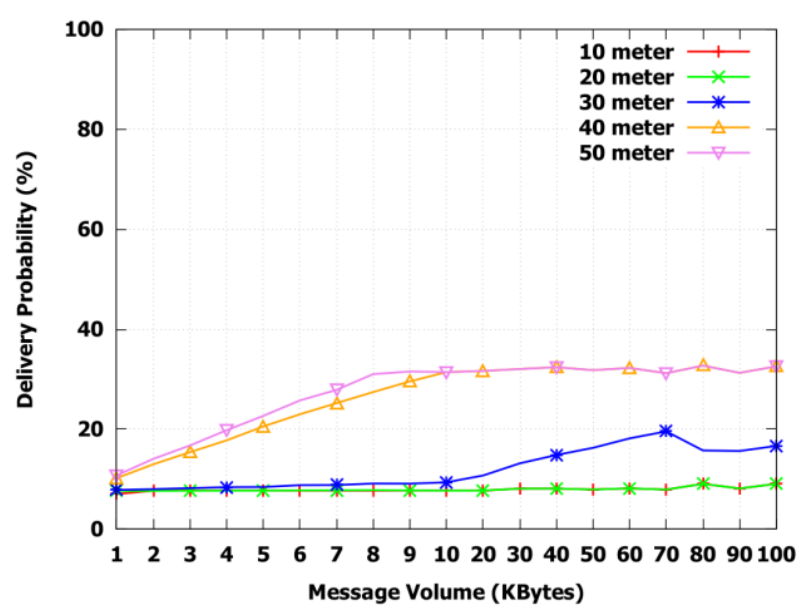

Figure.14 PRoPHETv2 with a buffer size of 10 MBytes

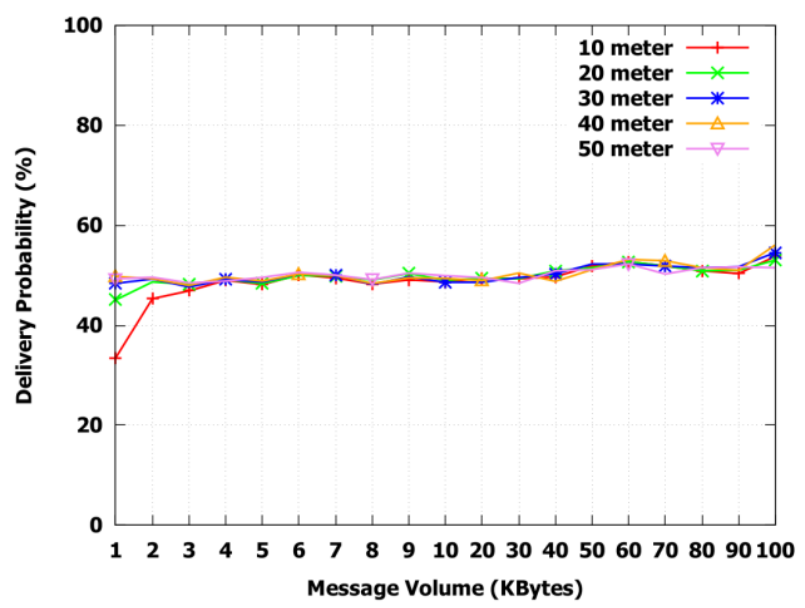

Figure.15 MaxProp with 1 MByte buffer size

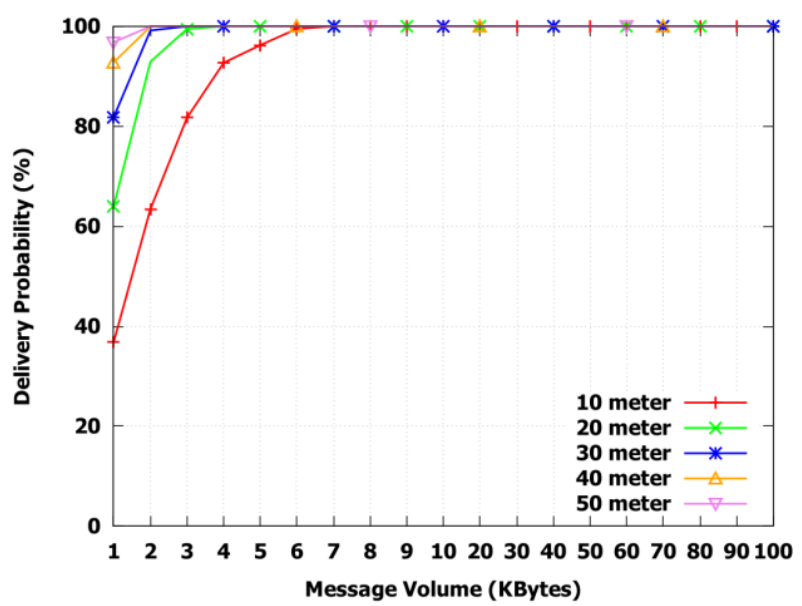

Figure.16 MaxProp with 5 MBytes buffer size

This protocol has three primary complementary mechanisms [40], namely: head start for new messages, lists of previous relay nodes, and acknowledgment of entire system. A "head start" is given to new messages to ensure that all messages have the opportunity to spread in the network. This indicates that priority is given to the delivery of these messages. Lists of previous relay nodes are 


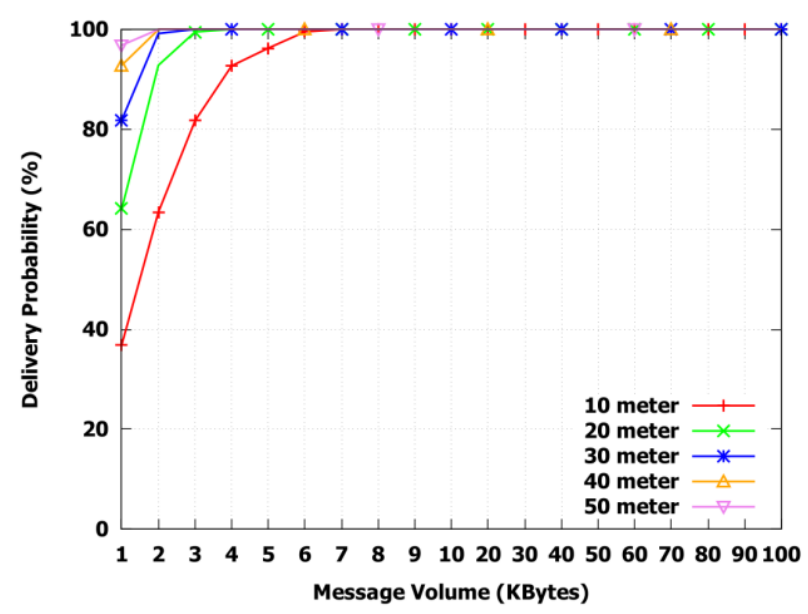

Figure.17 MaxProp with 10 MBytes buffer size

maintained to prevent messages from being sent to the same relay node. Acknowledgment of the entire system is deployed in the network to notify nodes to eliminate redundant copies of messages that have already been sent to their destination.

Figures 15 to 17 show that by increasing the buffer size causes increased delivery probability about 2 times, reaching 100\% (5 MBytes) compared to approximately $50 \%$ (1 MByte). The delivery probability of $100 \%$ with a message of 7 KBytes to 100 KBytes reached on the buffer size of 5 and 10 MBytes. However, the size of 1 KByte message with the number of message of 13200 still cannot reach $100 \%$ even if the buffer size is increased from 5 MBytes to 10 MBytes and the transmit range is 50 meters. The MaxProp shows better results than the epidemic on the buffer size of 1 MByte and 5 MBytes. Furthermore, the MaxProp is better at using the buffer size than the epidemic.

\section{Conclusion}

Based on the results presented in Section 3, the MaxProp routing protocol is best applied to the transport system scheduled which the relay nodes encounter the sources and the destinations once in a day. The MaxProp has shown the best delivery probability at 5 MBytes buffer size compared to the epidemic reached at the buffer size of 10 MBytes. The MaxProp is able to send $100 \%$ messages of 7 KBytes to 100 KBytes in all the transmit ranges and the buffer size of 5 and 10 MBytes. However, the MaxProp has not been able to send $100 \%$ for the 13200 messages of 1 KByte with the furthest transmit range is 50 meters and the largest buffer size is 10 MBytes. After the MaxProp, the order of the rest routing protocols according to its quality from the highest to the lowest is presented as follows: the epidemic, the first-contact, the PRoPHETv2, and the PRoPHET. However, all the routing protocols produce better delivery probability on larger size and smaller number of messages.

In future work, the investigation will be conducted to gather information along the railway line by relay nodes. The information is sent to cities from villages by relay nodes. It is interesting to do because relay nodes serve the source and destination and meet with other relay nodes only once in a day. The most appropriate routing protocol will be selected or the routing protocol will be modified for the dissemination and gathering of information.

\section{Acknowledgments}

This work was partially supported by Ministry of Research, Technology, and Higher Education, Indonesia under the PUPT grant number 751/UN1P.III/LT/DIT-LIT/2016 and was conducted in the Department of Electrical Engineering and Information Technology, Faculty of Engineering, Universitas Gadjah Mada, Yogyakarta, Indonesia.

\section{References}

[1] K. K. dan Informatika, Kementerian kominfo sebarkan informasi bencana melalui media center, https://kominfo.go.id/content/detail/ 3774/kementerian-kominfo-sebarkan-informasi-bencana-melalui-mediacenter/0/berita_satker, 2014.

[2] K. K. dan Informatika, Hingga 2014 kemkominfo telah bangun 195 media center daerah, https://kominfo.go. $\mathrm{id} /$ content/detail/4689/hingga-2014kemkominfo-telah-bangun-195-media-centerdaerah/0/berita_satker, 2015.

[3] K. K. dan Informatika, Hibah aset 35 media center jadi milik daerah, https://kominfo.go.id/content/detail/6674/hibah -aset-35-media-center-jadi-milikdaerah/0/berita_satker, 2016.

[4] K. K. dan Informatika, Kemenkominfo hibahkan media center pada 35 pemerintah kabupaten/kota,

https://kominfo.go.id/content/detail/6681/keme nkominfo-hibahkan-media-center-pada-35pemerintah-kabupatenkota/0/sorotan_media, 2016.

[5] K. K. dan Informatika, Kementerian kominfo serahkan bantuan 20 kendaraan m-pustika roda dua dan roda empat, https://kominfo.go.id/content/detail/3735/keme nterian-kominfo-serahkan-bantuan-20kendaraan-m-pustika-roda-dua-dan-rodaempat/0/berita_satker, 2014. 
[6] K. K. dan Informatika, Yuk, intip isi mobil pintar kominfo, https://kominfo.go.id/content/detail/2457/yukintip-isi-mobil-pintar-

kominfo/0/sorotan_media, 2013.

[7] K. K. dan Informatika, Menteri desa: "layar desa" solusi keterbatasan informasi, https://kominfo.go.id/content/detail/4975/ment eri-desa-layar-desa-solusi-keterbatasaninformasi/0/sorotan_media, 2015.

[8] R. J. Akbar and R. A. Rachman, 74 ribu desa tertinggal akan dipasangi layar raksasa, http://bisnis.news.viva.co.id/news/read/624550 -74-ribu-desa-tertinggal-akan-dipasangi-layarraksasa, 2015.

[9] K. K. dan Informatika, Media center untuk percepatan penyebaran informasi, https://kominfo.go.id/content/detail/7382/medi a-center-untuk-percepataninformasi/0/berita_satker, 2016.

[10] M. Wijaya, Kominfo bangun media center daerah, http://kantin.id/2016/12/10/kominfobangun-media-center-daerah/, 2016.

[11] J. Crowcroft, E. Yoneki, P. Hui, and T. Henderson, "Promoting Tolerance for Delay Tolerant Network Research", ACM SIGCOMM Computer Communication Review, Vol.38, No.5, pp.63-68, 2008.

[12] A. G. Voyiatzis, "A Survey of Delay- and Disruption-Tolerant Networking Applications", Journal of Internet Engineering, Vol.5, No.1, pp.331-344, 2012.

[13] V. Cerf, S. Burleigh, A. Hooke, L. Torgerson, R. Durst, K. Scott, K. Fall, and H. Weiss, "Delay-tolerant networking architecture", $R F C$ 4838, 2007.

[14] W. M. Eddy, "Assessing the Bundle Protocol (BP) and alternative approaches to data bundling in delay-tolerant networks (DTNs)", In: Advances in Delay-tolerant Networks (DTNs): Architecture and Enhanced Performance, ser. Woodhead Publishing Series in Electronic and Optical Materials. Boston, MA: Elsevier, No.67, pp.139-157, 2015.

[15] L. Wood, W. M. Eddy, and P. Holliday, "A bundle of problems", In: 2009 IEEE Aerospace Conference Proceedings. Piscataway, NJ, USA: IEEE; Big Sky, MT: IEEE, pp.1-17, 2009.

[16] A. S. Pentland, R. Fletcher, and A. Hasson, "DakNet: Rethinking connectivity in developing nations", IEEE Computer, Vol.37, No.1, pp.78-83, 2004.

[17] S. Guo, M. Derakhshani, M. Falaki, U. Ismail, R. Luk, E. Oliver, S. U. Rahman, A. Seth, M.
Zaharia, and S. Keshav, "Design and implementation of the KioskNet system", Computer Networks, Vol.55, No.1, pp.264-281, 2011.

[18] E. M. Husni and A. R. Sumarmo, "Delay tolerant network utilizing train for news portal and email services", In: Proc. of the Information and Communication Technology for the Muslim World (ICT4M), 2010 International Conference on. IEEE, pp.G6-G10, 2010.

[19] E. M. Husni, "Rural Internet Service System based on Delay Tolerant Network (DTN) using train system", In: Proc. of the Electrical Engineering and Informatics, 2011 International Conference on. Bandung, Indonesia: IEEE, 2011.

[20] E. Husni and A. Wibowo, "E-mail System for Delay Tolerant Network", In: Proc. of the System Engineering and Technology (ICSET), 2012 International Conference on. Bandung. IEEE, pp.1-7, 2012.

[21] R. Luk, M. Ho, and P. M. Aoki, "A Framework for Designing Teleconsultation Systems in Africa", In: Proc. of the International Conference on Health Informatics in Africa (HELINA), Bamako, Mali, Vol.abs/0801.1925, pp.1-5, 2007.

[22] R. Luk, M. Ho, and P. M. Aoki, "Asynchronous Remote Medical Consultation for Ghana", In: Proc. of the twenty-sixth annual SIGCHI conference on Human factors in computing systems (CHI '08), ser. CHI '08. New York, NY, USA: ACM, pp.743-752, 2008.

[23] R. Luk, M. Zaharia, M. Ho, B. Levine, and P. M. Aoki, "ICTD for healthcare in Ghana: two parallel case studies", In: Proc. of the 2009 International Conference on Information and Communication Technologies and Development (ICTD). Doha: IEEE, pp.118-128, 2009.

[24] A. Lindgren, A. Doria, J. Lindblom, and M. Ek, "Networking in the Land of Northern Lights: Two Years of Experiences from DTN System Deployments", In: Proc. of the 2008 ACM workshop on Wireless networks and systems for developing regions (WiNS-DR '08), ser. WiNS-DR '08. New York, NY, USA: ACM, pp.1-8, 2008.

[25] A. Lindgren and P. Hui, "ExtremeCom: To Boldly Go Where No One Has Gone Before", ACM SIGCOMM Computer Communication Review, Vol.41, No.1, pp.54-59, 2011.

[26] P. Ginzboorg, T. Krkkinen, A. Ruotsalainen, M. Andersson, and J. Ott, "DTN Communication 
in a Mine", In: Proc. of the Extreme Workshop on Communication - The Himalayan Expedition (ExtremeCom 2010), pp.1-6, 2010.

[27] P. Juang, H. Oki, Y. Wang, M. Martonosi, L. S. Peh, and D. Rubenstein, "Energy-efficient Computing for Wildlife Tracking: Design Tradeoffs and Early Experiences with ZebraNet", SIGARCH Comput. Archit. News, Vol.30, No.5, pp.96-107, 2002.

[28] P. Zhang, C. M. Sadler, S. A. Lyon, and M. Martonosi, "Hardware Design Experiences in ZebraNet", In: Proc. of the 2nd International Conference on Embedded Networked Sensor Systems, USA: ACM, pp.227-238, 2004.

[29] J. Burgess, B. Gallagher, D. Jensen, and B. N. Levine, "MaxProp: Routing for Vehicle-Based Disruption-Tolerant Networks", In: Proc. of the INFOCOM, ser. (ISSN) 0743-166X, Vol.6. Barcelona, Spain: IEEE, pp.1-11, 2006.

[30] K. Zaragoza, N. Thai, and T. Christensen, "An Implementation for Accessing Twitter Across Challenged Networks", In: Proc. of the 6th ACM Workshop on Challenged Networks (CHANTS '11), USA: ACM, pp.71-72, 2011.

[31] A. Balasubramanian, Y. Zhou, W. B. Croft, B. N. Levine, and A. Venkataramani, "Web Search from a Bus", In: Proc. of the Second ACM Workshop on Challenged Networks (CHANTS '07), ser. CHANTS '07, USA: ACM, pp.59-66, 2007.

[32] S. B. Eisenman, E. Miluzzo, N. D. Lane, R. A. Peterson, G.-S. Ahn, and A. T. Campbell, "BikeNet: A Mobile Sensing System for Cyclist Experience Mapping”, ACM Transactions on Sensor Networks (TOSN), Vol.6, No.1, pp.6:1-6:39, 2009.

[33] M. Niswar, Mukarramah, and Agussalim, "Evaluasi kinerja protokol routing pada delay tolerant network," In: Hasil Penelitian Fakultas Teknik, Prosiding 2012, Vol.6. Makassar, Indonesia: Group Teknik Elektro, 2012.

[34] L. Lambrinos, C. Djouvas, and C. Chrysostomou, "Applying delay tolerant networking routing algorithms in maritime communications", In: Proc. of the World of Wireless, Mobile and Multimedia Networks (WoWMoM), 2013 IEEE 14th International Symposium and Workshops on a. Madrid: IEEE, pp. 1-6, 2013.

[35] D. J. P. R. D. P. Umum, Peraturan menteri pekerjaan umum nomor: 05/prt/m/2008 tentang pedoman penyediaan dan pemanfaatan ruang terbuka hijau di kawasan perkotaan, Direktorat Jenderal Penataan Ruang
Departemen Pekerjaan Umum, http://www.bkprn.org/peraturan/the file/permen05-2008.pdf, Tech. Rep., 2008.

[36] P. T. K. A. I. (Persero), Jadwal Perjalanan Kereta Api 2015, Jl. Perintis Kemerdekaan No.1 Bandung: PT. Kereta Api Indonesia, 2015.

[37] S. Jain, K. Fall, and R. Patra, "Routing in a delay tolerant network", In: Proc. of acm sigcomm 2004 conference on applications, technologies, architectures, and protocols for computer communication, ed. Portland, Oregon, USA: ACM, Vol.34, No.4, Sep. 2004.

[38] A. Vahdat and David Becker, "Epidemic Routing for Partially-Connected Ad Hoc Networks", Technical Report CS-200006, Duke University, Tech. Rep., 2000.

[39] S. Misra, B. Saha, and S. Pal, Opportunistic Mobile Networks: Advances and Applications, ser. Computer Communications and Networks. Switzerland: Springer International Publishing Switzerland, ch. Chapter 2 Delay Tolerant Routing and Applications, pp.23-52, 2016.

[40] J. J. P. C. Rodrigues and V. N. G. J. Soares, Advances in Delay-tolerant Networks (DTNs): Architecture and Enhanced Performance, ser. Woodhead Publishing Series in Electronic and Optical Materials. 80 High Street, Sawston, Cambridge, CB22 3HJ, UK: Elsevier, Vol.67, ch. Chapter 1 An introduction to delay and disruption-tolerant networks (DTNs), pp.1-21, 2015.

[41] A. Lindgren, A. Doria, and O. Scheln, "Probabilistic routing in intermittently connected networks", ACM SIGMOBILE mobile computing and communications review, Vol.7, No.3, pp.19-20, 2003.

[42] S. Grasic, E. Davies, A. Lindgren, and A. Doria, "The evolution of a DTN routing protocol-PRoPHETv2," In: CHANTS '11 Proc. of the 6th ACM workshop on Challenged networks, Las Vegas, Nevada, USA: New York, NY, USA: ACM, pp.27-30, 2011. 